\title{
Overview of Relevant Regional Culture Studies (the Krasnoyarsk Krai): Challenges and Approaches
}

\author{
Kseniya A. Degtyarenko*, Svetlana V. Metlyaeva, \\ Daria S. Pchelkina, Antonina I. Fil'ko, \\ Anna A. Shpak, Mikhail Ya. Khrebtov \\ and Kseniya I. Shimanskaya \\ Siberian Federal University \\ 79 Svobodny, Krasnoyarsk, 660041, Russia
}

Received 07.07.2019, received in revised form 02.08.2019, accepted 09.08.2019

This article presents the results of the analysis of relevant regional culture studies. The purpose of this analysis was to determine which areas of cultural research in the modern world are the most promising ones in terms of studying the culture of the regions. Not only the articles of foreign authors were particular examples therein, but also culture studies conducted directly in the Krasnoyarsk Krai. The overview allows to conclude that studies in the following areas are relevant for the Krasnoyarsk Krai at the moment: ethnocultural processes, ethnic identity and its development, transformation of ethnic identity, language and culture of indigenous peoples of the North, migration processes, urban studies, contemporary art, art mediation, musical folklore, the concepts of "war" and "peace".

Keywords: culture studies, the Arctic, Krasnoyarsk Krai, regional studies, ethnocultural processes, ethnic identity, art mediation, contemporary art, concept, urban studies.

Research area: art studies; culturology.

Citation: Degtyarenko, K.A., Metlyaeva, S.V., Pchelkina, D.S., Fil'ko, A.I., Shpak, A.A., Khrebtov, M. Ya., Shimanskaya, K.I. (2019). Overview of relevant regional culture studies (the Krasnoyarsk Krai): challenges and approaches. J. Sib. Fed. Univ. Humanit. soc. sci., 12(8), 1568-1588. DOI: 10.17516/1997-1370-0465.

\section{Introduction}

Many researchers note that cultural studies are currently on the rise. Particular attention is paid to applied research on regional processes in culture. In modern works, a combination of applied and theoretical research is particularly relevant.

(C) Siberian Federal University. All rights reserved

* Corresponding author E-mail address: decanka@mail.ru; akseniya.krupkina@mail.ru ORCID: 0000-0002-0049-9417 (Metlyaeva); 0000-0002-2787-423X (Fil'ko)

This work is licensed under a Creative Commons Attribution-NonCommercial 4.0 International License (CC BY-NC 4.0). 
The purpose of this article is to consider the key urgent problems of cultural research pointed out in the works of various authors related to the regional aspects of culture studies. This overview includes the classification of the main topics of current research, both in world practice and in the Krasnoyarsk Krai. As a result, it was possible to determine such areas of research as ethnocultural processes, ethnic identity and its development, art mediation, transformation of ethnic identity, contemporary art, musical folklore, the concepts of "war" and "peace", the language and culture of the indigenous peoples of the North, urban studies. A detailed overview of these areas is presented below.

\section{Challenges of ethno-cultural processes.}

Within the framework of studying small-numbered indigenous peoples of the Krasnoyarsk Krai, special attention is paid to the study of changes and transformation processes among ethnic groups of the northern areas of the Krasnoyarsk Krai.

V.P. Krivonogov has been studying small-numbered indigenous Siberian peoples and challenges of ethno-cultural processes in long-term ethno-graphic studies. The ethnographer pays specific attention to progressing processes of miscegenation and language assimilation among indigenous peoples of the Krasnoyarsk Krai, as well as pattern policy of the state as humanitarian technology for preservation and maintenance of ethno-cultural identity of indigenous peoples (Krivonogov, 2006).

The work by N.P. Koptseva, A. N. Khizhnyakova and K. V. Reznikova considers language interrelations of the indigenous people of the north of the Krasnoyarsk Krai (Koptseva, Khizhnyakova, Reznikova, 2011).

N.P. Koptseva, N.N. Pimenova and K.V. Reznikova in their research pay attention to the problem of cultural changes among small indigenous peoples living in communities in the north of the Krasnoyarsk Krai connected with global processes (Koptseva, Pimenova, Reznikona, 2010; Reznikova et al., 2016; Koptseva, \& Kirko, 2014a, 2014b, 2014c, 2014d; Reznikova, et al., 2017)., Scientists suggest to use cultural anthropology as part of the study of the current state of indigenous peoples. N.M. Libakova and E. A. Sertakova consider the method of expert interviews in the study of the northern territories (Libakova, Sertakova, 2014).

K. V. Reznikova, based on a field study conducted in 2010, explores the possibilities of preserving and changing the traditional side of life of the indigenous peoples of the Turukhansky municipal district (Reznikova, 2013).

The works by V.S. Luzan provide an analysis of Russian and international legislation regarding indigenous peoples, as well as the study of the mechanisms of 
state-business interaction among the indigenous peoples of the northern territories of the Krasnoyarsk Krai (Luzan, 2014, 2015).

\section{Relevant problems of the transformation of ethnic identity and mechanisms for the development of ethnic identity}

The phenomenon of ethnic identity is the subject of scientific discussion of representatives of almost all fields of the humanities. Therefore, scientists consider various aspects of this phenomenon. Ethnic identity is embodied through an ethnonym and is a conscious act of self-determination of a person through self-awareness as a unit of a certain ethnic group.

The challenges in studying ethnic identity are associated with a wide range of nominated meanings of this concept. There are many conceptual models and their interpretations. However, notwithstanding a large number of publications devoted to this topic, the phenomenon has not been completely and objectively covered. For example, researchers agree on the social nature of any identity, including ethnicity. According to this opinion, identity seems to be a structure subject to transformation processes, but studies on these processes are not common. Nevertheless, there have always been works that fully represent the specifics of the structure of ethnic identity, factors of changes in ethnic identity in historical dynamics analysing the current state of the phenomenon and the influence of modern factors thereupon, etc.

Which areas of research should be identified? M.S. Batashev, V. N. Ignatov, G. I. Lukyanov, N.P. Makarov, S. Ya. Palchin and A. S. Scherbakova have focused on the ethnogenesis of various ethnic groups. The specifics of the legal regulation of the socio-cultural development of these peoples have been investigated by I. Yu. Antonov, V.S. Luzan, K. G. Filant, S. N. Kharyuchi. E. A. Goroshko, T. A. Spirina and M. O. Makusheva are engaged in the research of the transformation of ethnic identity during the student years. V.I. Kirko, N.P. Koptseva and K. V. Reznikova have been studying traditional activities, cultural characteristics and customs with the suggestion of conservation practices. D. R. Gilyazeva, V.P. Krivonogov, D. G. Sevoyan and A.P Suntsov have focused on the language situation. The extremely relevant aspect of globalisation and its influence on the change of ethnic identity is considered by F. S. Androsova,
S. G. Antsupova,
M. S. Kuropyatnik,
G. M. Parnikova,
O. A. Povoroznyuk, D. A. Funk and V. I. Shadrin. 
Another aspect of the study of indigenous peoples of the Krasnoyarsk Krai is researching of the mechanisms for constructing the ethnocultural identity of indigenous peoples.

S. A. Podyapolsky and A. A. Gruzdev consider modern humanitarian technology as a mechanism of soft influence on certain communities and the ethnocultural processes occurring therein (Gruzdev, Pod"yapol'skii, 2013). The use of the possibilities of fine and decorative art in the process of ethnic identification of indigenous peoples is especially noteworthy among the effective modern humanitarian technologies for constructing the ethnocultural identity of indigenous minorities (in addition to paternalistic policy). This direction is supported by N.P. Koptseva (Koptseva, Pimenova, Seredkina, 2013), A. V. Kistova (Kistova, Pimenova, 2010), N. N. Pimenova (Pimenova, 2015), A. A. Sitnikova (Semenova, 2011), M. I. Bukova (Il'beikina, 2013) and others.

The scientific construction of an ethnos is considered in the works by N. P. Koptseva, K. V. Reznikova et al. (Koptseva, Pimenova, Reznikova, 2010). The study of socio-psychological attitudes to positive identity as a mechanism for constructing ethnocultural identity is being studied by N. N. Pimenova (Pimenova, 2015).

\section{Studies of language and culture of the small-numbered indigenous peoples of the North}

Currently the problem of the study and preservation of the languages and culture of indigenous peoples is especially relevant. For the Krasnoyarsk Krai, this is primarily the research of the indigenous peoples of the North.

N.A. Silantyeva (Silantyeva, 2015) examines various political, social, economic and cultural problems that the indigenous peoples of the North face at the present stage of development.

Measures on preserving the language of indigenous peoples are studied by Yu. S. Zamaraeva, N. A. Sergeeva, A. I. Filko (Zamaraeva, 2018; Zamaraeva, et al., 2018). Based on the questionnaire and expert interviews, the researchers determine the measures on preservation of the language, which, according to the majority, should help in preserving the unique cultural heritage of the small-numbered indigenous peoples of the Evenki municipal district.

N.K. Fayzullina (Fayzullina, 2015) studies the creation of the written language of the indigenous peoples living in the north of Western Siberia - the Khanty and the Mansi - and the organisation of schooling of school-age children in their native language. 
The development of modern educational methods for the small-numbered indigenous peoples of the North, Siberia and the Far East is quite relevant. Researchers M. A. Kolesnik, N.P. Koptseva， N.M. Libakova， E. A. Sertakova， K.V. Reznikova， N. N. Seredkina, and M. G. Smolina (Kolesnik et al., 2018; Koptseva, and Reznikova, 2015; Koptseva, et al., 2017; Seredkina, and Smolina, 2018) analyse the possibilities of contemporary art education as an effective tool for preserving the ethnocultural identity of the indigenous peoples of the North of the Krasnoyarsk Krai. A. A. Sitnikova, N. N. Pimenova, A. I. Filko (Sitnikova et al., 2018) consider modern effective pedagogical approaches in higher education and develop a system of practical actions to create an adaptive environment in the educational space of a university for graduates from indigenous minorities of the North on the material of the Krasnoyarsk Krai.

\section{Migration studies}

A significant part of regional culture studies is devoted to the problems of migration, processes of self-identification and integration of migrants.

Yu. S. Zamaraeva reveals an essential understanding of migration within the framework of the philosophy of culture, through linguocultural analysis of the content of the concept of "migration" (Zamaraeva, 2014). The work by K. V. Reznikova is devoted to the study of the image of migrants in the views of students of Siberian Federal University (Reznikova, 2016).

The problem of self-identification of migrants and migration processes in the Krasnoyarsk Krai can be traced in the works by A.V. Kistova, who considers the vectors of the influence of ethnic migration processes on the self-determination of the Chulymtsy ethnic group living in the Tyukhtet district of the Krasnoyarsk Krai (Kistova, 2015), A. A. Sitnikova, who studies the demographic and migration processes of indigenous peoples of the Krasnoyarsk Krai (Sitnikova, 2015). E. A. Sertakova and E. Yu. Avdonina are involved in the analysis of cinematographic works that touch upon migration (Sertakova and Avdonina, 2016). Yu. N. Avdeeva explores the importance of cultural memory as a form of transmission and actualisation of cultural meanings in the process of self-identification of migrants (Avdeeva, 2019).

\section{Urban studies}

Urban studies are an essential part of modern research while the modern age is the age of urbanisation and the most important sociocultural processes occur in the urban space mainly. 
The problems of the symbolism of the urban environment and the meanings of various symbols are considered by S. Dembski, L. R. Mijatović, P. J. Nas, M. De Groot, M. Schut, H.-D. Evers, E. Bakker, K. Saentaweesook, M. Stigwag, P. De Giosa, R.-A. Vermeer, S. Hettig, B. Bossak-Herbst, R. van Leeuwen, J. Luo, E. Durr, G. Kay, L.A. Hirfan and B.B. Momani (Nas, 2011, Mijatović, 2014). When considering signs and symbols in the city, many researchers turn to semiotic analysis (Stas', 2012, Rezanova, 2012, Iurenkova, 2014) and to studies of elements of urban space (Sihlongonyane, 2015, Weina, 2009, Utaberta, 2012).

Many researchers pay special attention to the studies of the remarkable places in the city. These can be both public spaces (Ferdous, 2013, Krase, Shortell, 2011), and places which are significant for the image of the city (Diagileva, Zhuravleva, 2012).

If we talk about Krasnoyarsk as the largest city in the Krasnoyarsk Krai, N.P. Koptseva, E. A. Sertakova and M.G. Smolina (Smolina et al., 2018) in their article outline the following modern areas of urban space research: diagnostics of the city ecology, monitoring of public opinion and the study of the causes of migration of educated youth, as well as aesthetic criticism of the territory, cataloguing of historical, cultural and architectural heritage, discussion of the urban plan and the problems of its implementation, as well as the problems of universal mobility of citizens, including the accessibility of the urban environment for disabled people.

M. V. Tarasova, A. A. Sitnikova, M. I. Ilbeikina, N. N. Pimenova, A. V. Kistova, E. A. Sertakova, M. A. Kolesnik and N.A. Bakhova in their works study the visual image of the city of Krasnoyarsk and its perception with the help of philosophical and art history analysis of art works in the urban environment (Sertakova, Koptseva, 2015; Mirkes, Sergeyeva, 2011; Kistova, et al., 2016; Koptseva, 2015; Karlova, Koptseva, 2013; Kolesnik, 2011).

\section{Studies of the contemporary art of the region}

Paying attention to the urgent problems of regional culture studies, it is worth paying attention to the specifics of contemporary art in the Krasnoyarsk Krai.

Considering regional problems, it is worth noting the development of the preservation of art works by indigenous peoples of the North. As noted by A. V. Kistova and N.P. Pimenova, the practices of preserving the cultural heritage of the indigenous peoples of the North and Siberia in the Krasnoyarsk Krai demonstrate prevailing academic approach forms: museumification, conservation, scientific research and reconstruction of art works. The researchers also note the development of the ways to actualise and preserve 
the cultural heritage of indigenous peoples (Kistova \& Pimenova, 2017). E. A. Sertakova and A. A. Gerasimova, in turn, note the problem of the loss of national identity by the inhabitants of the region and the growing continuity of American and European cultures (Sertakova, \& Gerasimova, 2015; Sertakova, et al., 2016). N. P. Koptseva, N. N. Pimenova and N.N. Seredkina consider the traditional religion and art of the indigenous peoples of the North as "a factor in the formation of a positive all-Russian cultural identity" and study the influence of modern ritual forms of culture and folk art on the formation of the positive ethnic identity (Koptseva, et al., 2013).

Contemporary art in the Krasnoyarsk Krai is presented by the art of indigenous peoples with the preservation of an original element, contemporary art reflecting the problems of modern society, conceptual art, art using the traditions of American and European cultures.

It is worth noting the type of exhibition sites on the example of the city of Krasnoyarsk: private galleries, open galleries of higher educational institutions, municipal cultural institutions. In other parts of the region, the type of municipal cultural institutions is most developed. Each type has its own specificity which depends on the material support and the state or commercial programme which in turn leads to the problem of the ratio of the aesthetic and commercial in art.

Touching upon the commercial side of art, it is necessary to note the development of the art market in the region as a complex social and cultural phenomenon, which in turn has an impact on the artistic life of the society and is strongly associated with material assessment of cultural values.

Similarly, one of the urgent problems of culture studies directly related to the functioning of contemporary art, is the practice of art mediation. Being a modern form of interaction between the museum and the audience, in accordance with the concept of Museum 2.0 introducing changes in its cultural and educational activities, art mediation is also a new way of interpreting works of art - with the viewer and for the viewer. An integral feature of it is the highest attention to the audience's individuality, the desire to generate "incomprehensible art" (contemporary, first of all) understandable, the viewer's motivation to perceive it on their own with the help of an art mediator.

The relevance of this topic for culture studies in the region is confirmed by the possibility of analysing art mediation in practice. Since 2018, the "Peace Square" museum in Krasnoyarsk, having adopted the experience of the Moscow Museum of Modern Art, has been applying art mediation practice in its work, thus having become a material for research (Moskalyuk et al., 2016; Burlutskaia et al., 2018). 
Understanding art mediation as a communicative practice uniting the viewer, the work of art, as well as the art mediator as an intermediary of their dialogue, allows for further theoretical understanding of the phenomenon of art mediation to turn to the key works of Krasnoyarsk scientists. Thus, according to the theory of fine art developed by V.I. Zhukovskii in collaboration with N. P. Koptseva (Zhukovskii and Koptseva, 2004), it is communication that makes the work of art authentic and provides benefits for the viewer. If it is under threat, according to V. I. Zhukovskii, an art historian should come to help both sides of communication as their vocation is to "professionally perform the adaptation function of a mediator between the work of art, on the one hand, and the viewer, on the other" (Zhukovskii, 2011). Further development of the theoretical concepts of the concept of artistic communication in relation to various types of fine art was undertaken by M.V. Tarasova (Tarasova, 2010, 2015), as well as by other authors.

Therefore, we can distinguish such problems of regional culture studies on the example of the Krasnoyarsk Krai in the field of contemporary art as the predominance of the academic approach forms, the loss of national identity by residents, the problem of the ratio of aesthetics and state or commercial programming of works of art, as well as the problem of the concept of artistic communication of the viewer with the work of art.

\section{Musical folklore of the Krasnoyarsk Krai}

Siberia is one of the largest regions of our country. The research of its musical culture has started quite recently. The study of musical folklore was completed by such outstanding scientists of the $20^{\text {th }}$ century as V.G. Vasilevich (Vasilevich, 1969), A. A. Makarenko (Makarenko, 1962), Yu. I. Sheikin (Sheikin, 2002), T. V. Pavlova (Pavlova, 1997) and others.

The conducted research contributed to the enrichment of the treasury of musical art by the unique collections of sound recordings, musical materials, as well as the collection of traditional musical instruments.

It is noteworthy that before the revolution the musical folklore of Siberia was practically not recorded, and therefore it is still interesting for modern researchers.

The Krasnoyarsk Krai is rightfully considered to be the centre of folk music and song art. Many songs of the region are famous for their rich intonation and rhythm variety. A. A. Makarenko (Makarenko, 1962) while exploring the musical folklore of the Yenisei province at the turn of the $19^{\text {th }}-20^{\text {th }}$ centuries noted a special love for songwriting and musical talent among the local population. 
Modern performers of folk songs in the Krasnoyarsk Krai are distinguished by subtlety and expressiveness of performance. A distinctive stylistic feature in their performance is a complex polyphony in lyric songs and heterophonic polyphony in a wedding ceremony. Sacred and historical songs have peculiar variable sound.

Similar artefacts of the song culture of the region have been recorded by researchers for more than a decade. A significant contribution to the collection of song folklore of the Krasnoyarsk Krai was made by the Krasnoyarsk composer F.P. Veselkov, N. A. Shulpekov, L. D. Ecard and others.

Currently the style and history of folk music and song art has been actively reviving. Folklore groups are annually created in the Krasnoyarsk Krai, which have become famous not only in the region, but throughout the country: Krasa music group (Krasnoyarsk), Krasnaya Rus music group (Borodino), Kheiro music group (Taimyr), and Sibirskaya Vechora (Krasnoyarsk).

\section{Studies of the "war" and "piece" concepts}

At the turn of the $20^{\text {th }}-21^{\text {st }}$ centuries scientists in the Krasnoyarsk Krai and other regions of Russia have outlined a cultural turn in understanding the concepts of "war" and "peace". During this period, the scope of the methodology has expanded, which led to the development of various research approaches: positivistic and postpositivistic, understanding and explaining, neo-Kantian and phenomenological, structuralist and post-structuralist (Senyavskaya, 2004). The study of the concepts of "war" and "peace" is in the peripheral state of various humanities. Namely, these sciences are history, sociology, philosophy, ethnology, psychology, political science, cultural science. The peripheral position of this problem makes its research difficult. The main research centres for studying the topics of "war" and "peace" in Russia are Moscow, St. Petersburg, Tomsk Oblast, and Novosibirsk Oblast; in other regions of Russia, these concepts are less popular among scientists. The Krasnoyarsk Krai and other Far Eastern regions do not have high-quality scientific research on the problems of "war" and "peace".

As a result of the activities of Russian scientists, Russian scientific literature devoted to "war" and "peace" was enriched by works on the military culture and subculture of various societies, states, and armies. Russian scientists who deal with this problem are N. S. Rozov, A. I. Pershits, Yu. I. Semenov, N. A. Korf, G. A. Leer, N. N. Golovin, Zabolotny, P.A. Sorokin, N.A. Timashev. V.I. Obraztsov, V.V. Serebryannikov, V.G. Andreev, V.V. Kruglov, V.I. Gamov, M.E. Sosnovsky, V. A. Shnirelman, 
V.P. Kultygin are modern authors with outstanding dissertations on this subject. Such cultural phenomena as "information war", "hybrid war", "political war", "psychological war", etc., which reflect the essence of modern concepts of "war" and "peace" came to the humanities from abroad (Gamov, 2000).

An important prerequisite for the study of "war" and "peace" concepts was the abolition of the "truth monopoly" of Marxism-Leninism in the field of methodology of social and human sciences (Grebenkov, 2009). Scientists were able to pay attention to the cultural aspects of military activity, trying to identify the influence of culture on the consciousness and behaviour of a person under war conditions (Bazhukov, 2009). This allowed us to reconsider these phenomena in Russian culture. An important area of study of "war" and "peace" concepts was the "informatisation of society", which in the $21^{\text {st }}$ century has had a great impact on the cultural development of these concepts. This led to the fact that "war" and "peace" begin to occupy such cultural spaces as the media, the Internet, social networks, etc., which erase the semantic contraposition of the concepts under consideration. The war in the $21^{\text {st }}$ century has a peaceful connotation. "War" and "peace" are now becoming identical concepts. These phenomena begin to exist inside each other becoming more and more integral parts of the whole, complementing one another.

Therefore, from the above it follows that, in connection with the development of world information technologies, political and economic instruments, scientific research of the concepts of "war" and "peace is extremely relevant for Russian society.

\section{Conclusion}

The analysis of regional cultural studies allowed to identify the most relevant areas for the Krasnoyarsk Krai, such as transformation processes among ethnic groups in the north of the region, as well as consideration of linguistic interactions of the indigenous peoples of the North. The article considers the problem of cultural changes among small indigenous peoples compactly living in the North of the Krasnoyarsk Krai and problems associated with global processes that affect the mechanisms of constructing the ethnocultural identity of indigenous peoples, which can be attributed to the problems of ethnic identity research. From the point of view of urban environment studies, it is worth highlighting the problems of symbolism of the urban environment and the meanings of various symbols. In the field of contemporary art, there are such problems of regional cultural studies as the predominance of the academic approach, the loss of national identity by residents, the problem of the correlation of aesthetics and state or 
commercial programming of art works, as well as the problem of the concept of artistic communication of the viewer with the work of fine art. Musical culture, in turn, has been little studied, which is one of the main challenges itself. As for the concepts of "war" and "peace", the main centres of research on this issue are the European part of Russia, Western Siberia and in Central Siberia (including the Krasnoyarsk Krai) and the Far East, these concepts are less popular. Thus, as a result of the analysis, the most demanded and promising areas of regional cultural research have been identified.

\section{References}

Androsova, F.S., Antsupova, S.G. \& Parnikova, G.M. (2018). Sokhranenie korennykh narodov respubliki Sakha (Iakutiia) v usloviyakh promyshlennogo osvoeniia Arktiki i krainego Severa [The Preservation of indigenous peoples of the Sakha Republic (Yakutia) in the conditions of industrial development of the Arctic and the far North]. In Mir nauki, kul'tury, obrazovaniia [The World of science, culture, education], 4 (71), 82-82

Avdeeva, Yu.N. (2019). Znachenie kul'turnoi pamiati migrantov dlia etnicheskoi samoidentifikatsii (na materiale Krasnoiarskogo kraia) [The value of cultural memory of migrants for ethnic identity (on the material of the Krasnoyarsk Krai)]. Krasnoyarsk, $168 \mathrm{p}$.

Batashev, M.S. (2013). Etnicheskaia istoriia korennykh narodov Eniseiskogo uezda [Ethnic history of the indigenous peoples of the Yenisei district]. In Zhurnal Sibirskogo federal'nogo universiteta [Journal of Siberian Federal University], 6 (6), 842-869.

Bazhukov, V.I. (2009). Voennaia antropologiia: metodologiia, napravleniia, sovremennoe sostoianie [Military anthropology: methodology, directions, current state]. Moscow, Max Press.

Burlutskaia, M.G., Kostina, D.A., Kochukhova, E.S., Kudriavtseva, I.V., Kuleva, M.I., Maksimova, A.S., ... Shirokova, E.A. (2018). "Chto-to novoe i neobychnoe": auditoriia sovremennogo iskusstva v krupnykh gorodakh Rossii ["Something New and Unusual": Audience of Modern Art in the Cities of Russia]. Yekaterinburg, Yekaterinburg Academy of Contemporary Art, 400 p.

Diagileva, N.S. \& Zhuravleva, L.A. (2012). Gorodskaia identichnost': poniatie, struktura, osnovy formirovaniia [Urban Identity: Concept, Structure, Basis of Formation]. In Sotsiologiia goroda [Sociology of the city], (1), 46-61.

Dreiling R.K. (1925). Russian military culture. Russian culture: Collection of articles. Belgrad, 67-74. 
Fayzullina, N.K. (2015). Problemy sozdaniia pis'mennosti i organizatsii obucheniia khanty i mansi na rodnom iazyke v 30-50-kh gg. XX v. [The problems of writing development and organization of teaching khanty and mansi their native language in the $30 \mathrm{~s}-50 \mathrm{~s}$ of the $20^{\text {th }}$ century]. In Severnyi region: nauka, obrazovanie, kul'tura [Northern region: science, education, culture], 2, 130-133.

Ferdous, F. (2013). Examining the Relationship between Key Visual Characteristics of Urban Plazas and Aesthetic Response. In SAGE Open, April-June, 1-10.

Gamov V.I. (2000). The Image of War in Culture [The Image of War in Culture]: dis. Doctor of Philosophy: 24.00.01. Theory and history of culture. Armavir. 343 p.

Gilyazeva, D.R. (2013). Mezhdunarodnye garantii dostupa korennykh narodov k zemle i resursam [International guarantees of access of indigenous peoples to land and resources]. In Pravo i politika [Law and policy], 3, 355-362.

Grebenkov, V.N. (2009) Voennaia kul'tura rossiiskogo obshchestva [Military culture of the Russian society]. Stavropol. In Stavropol State University.

Gruzdev, A.A. \& Pod"yapol'skii, S.A. (2013). Gumanitarnye tekhnologii kak “oboiudoostroe oruzhie" v bor'be za napravlennost' etnokul'turnykh processov [Humanitarian technologies as a "double-edged weapon" in the struggle for the direction of ethnocultural processes]. In Nauka i biznes: puti razvitiia [Science and business: ways of development], 9 (27), 25-28.

Il'beikina, M.I. (2013). Rol'vizual'noi antropologii v sotsial'nom konstruirovanii tsennostei [The role of visual anthropology in the social construction of values]. Krasnoyarsk, 21 p.

Iurenkova, E.A. (2014). Reprezentatsiia vizual'nykh obrazov goroda Ivanovo v vidovykh otkrytkakh [Representation of visual images of the city of Ivanovo in the species postcards]. In Izvestiia vuzov. Seriia "Gumanitarnye nauki" [Proceedings of universities. Series “Humanities”], 5 (2), 151-156.

Karlova, O.A. \& Koptseva, N.P. (2013). Novoe budushchee Sibiri: ozhidaniia, vyzovy, resheniia [New Future of Siberia: Expectations, Challenges, Solutions]. Krasnoyarsk, 508 p.

Kharyuchi, S.N., Filant, K.G. \& Antonov, I. Yu. (2009). Sotsial'nye normy korennykh malochislennykh narodov Severa Rossii. Obriady, obychai, ritualy, traditsii, mify, normy morali, normy prava [Social norms of indigenous peoples of the North of Russia. Rites, customs, rituals, traditions, myths, morality, law]. Moscow, Uniti-Dana, 280.

Kistova, A., Pimenova, N., Reznikova, Zamaraeva, K., Koptseva, N., Seredkina, N. \& Filko, A. (2016). Place management: Decoding the visual image of a Siberian city. In Journal of Applied Economic Sciences, 11(6), 1143-1155. 
Kistova, A.V. \& Pimenova N.N. (2017). Dekorativno-prikladnoe iskusstvo korennykh narodov, prozhivaiushchikh na territorii Evenkiiskogo i Taimyrskogo munitsipal'nykh raionov [Decorative and applied arts of indigenous peoples living in the territory of Evenkiysky and Taimyr municipal districts]. In Sibirskii Antropologicheskii Zhurnal [Siberian Anthropology Journal], 1 (3), 72-92.

Kistova, A.V. \& Pimenova, N.N. (2010). Dekorativno-prikladnoe iskusstvo korennykh malochislennykh narodov Severa kak etnoformiruiushchii komponent kul'tury: vizualizatsiia religii $\mathrm{v}$ pamiatnikakh iskusstva [Decorative and applied art of the indigenous minorities of the North as an ethno-forming component of culture: visualization of religion in art monuments]. In Tretii Vserossiiskii kul'turologicheskii kongress $s$ mezhdunarodnym uchastiem "Kreativnost' v prostranstve traditsii i innovatsii” [Third All-Russian Culturological Congress with international participation "Creativity in the space of tradition and innovation"']. Saint Petersburg, 90-91.

Kistova, A.V. (2013). Konstruirovanie etnokul'turnoi i obshchenatsional'noi identichnostei na osnove etnograficheskogo podkhoda $\mathrm{V}$ sotsial'noi filosofii [Constructing ethnocultural and national identities based on the ethnographic approach in social philosophy]. Krasnoyarsk, 22 p.

Kistova, A.V. (2015). Vliianie etnicheskikh migratsionnykh processov na samoopredelenie korennykh malochislennykh narodov Sibiri (na primere etnicheskoi gruppy "Chulymtsy" Tiukhtetskogo raiona Krasnoiarskogo kraia [Influence of ethnic migration processes on the self-determination of the indigenous peoples of Siberia (on the example of the Chulytsy ethnic group of the Tyukhtetsky district of the Krasnoyarsk Krai)]. In Sovremennye problemy nauki i obrazovaniia [Modern Problems of Science and Education], 1(1), 228

Kolesnik, M.A. \& Mirkes, M.M. (2011). Principles of Symmetry in the Krasnoyarsk City Space and Processes of the Regional Identity. In Journal of Siberian Federal University. Humanities \& Social Sciences. 4 (12), 1727-1742.

Kolesnik, M.A., Libakova, N.M. \& Sertakova, E.A. (2018). Art education as a way of preserving the traditional ethnocultural identity of indigenous minority peoples from the North, Siberia and the Far East. In Novosibirsk State Pedagogical University Bulletin, 8 (4), 233-247.

Kopsteva N. P., Pimenova N. N., \& Reznikona K. V. (2010). Protection and Development of the Indigenous Peoples Living in Circumpolar Territories: Cultural and Anthropological Analysis. In Journal of Siberian Federal University. Humanities \& Social Science, 5, 3, 649-666. 
Koptseva, N.P. \& Kirko, V.I. (2014a). Specificity of ethnogeny indigenous peoples by Central Siberia in the transition from the traditional type of society to modern society. In Life Science Journal, 11(7), 409-413.

Koptseva, N.P. \& Kirko, V.I. (2014b). The information basis for formation of positive ethnic identities in the process of acculturation of indigenous peoples of the Arctic Siberia (Krasnoyarsk, Russia). In Life Science Journal, 11(8), 479-483.

Koptseva, N.P. \& Kirko, V.I. (2014c). Ethic identification of indigenous people of the Siberian Arctic. In American Journal of Applied Sciences, 11(9), 1573-1577.

Koptseva, N.P. \& Kirko, V.I. (2014d). Modern specificity of legal regulation of Cultural Development of the Indigenous Peoples of the Arctic Siberia (the Altay Region, the Zabaikailsky Region, Republic of Buryatia, Russia). In Life Science Journal, 11(9), 314-319.

Koptseva, N.P. \& Reznikova, K.V. (2015). Refinement of the causes of ethnic migration North Selkups based on the historical memory of indigenous ethnic groups Turukhansk district of Krasnoyarsk Krai. In Bylye gody, (38), 1028-1038.

Koptseva, N.P. (2013). K voprosu o sokhranenii i vosproizvodstve traditsionnoi kul'tury korennykh malochislennykh narodov Severa, Sibiri i Dal'nego Vostoka v Sibirskom federal'nom okruge [On the preservation and reproduction of traditional culture of indigenous peoples of the North, Siberia and the Far East in the Siberian Federal district]. In: NB: Problemy obshchestva i politiki [NB: Problems of society and politics], 12, 1-16.

Koptseva, N.P. (2015). Novaia art-kritika na beregakh Eniseia: monografia [New art critic on the banks of the Yenisei: monograph]. Krasnoyarsk, SibFU.

Koptseva, N.P., Pimenova, N.N. \& Seredkina, N.N. (2013). Izuchenie dekorativnoprikladnogo iskusstva i traditsionnykh religii korennykh malochislennykh narodov Severa kak faktor formirovaniia pozitivnoi obshcherossiiskoi kul'turnoi identichnosti [The study of arts and crafts and traditional religions of the indigenous peoples of the North as a factor in the formation of a positive all-Russian cultural identity]. In Pedagogika iskusstva [Art Pedagogics], 2, 15-30.

Koptseva, N.P., Reznikova, K.V., \& Kirko, V.I. (2017). The Political Struggle for Evenkia's "Special Status" Within Krasnoyarsk Krai (Central Siberia). In Asian Politics \& Policy, 9(1), 99-121.

Koptseva, N.P., Khizhnyakova, A.N. \& Reznikova, K.V. (2011). LinguisticCulturological Peculiarities of National Languages of the Northern People of the Krasnoyarsk Region. In Journal of Siberian Federal University. Humanities \& Social Sciences. 3 (4), 323-341. 
Krase, J. \& Shortell, T. (2011) On the Spatial Semiotics of Vernacular Landscapes in Global Cities. In Visual Communication, 10 (3), 367-400.

Krivonogov, V.P. (2006) Etnicheskoe razvitie korennykh narodov Taimyra [Ethnic development of the indigenous peoples of Taimyr]. In Krasnoiarskomu kraiutvorchestvo molodykh issledovatelei: materialy III molodezhnoi regional'noi nauchnoprakticheskoi konferentsii [Krasnoyarsk Territory - the work of young researchers: Proceedings of the III Youth Regional Scientific and Practical Conference]. KrasGu, 141-149.

Krivonogov, V.P. (2013). Etnicheskoe samosoznanie i iazykovye protsessy u dolgan [Ethnic identity and language processes in Dolgan]. In Zhurnal Sibirskogo federal'nogo universiteta. - Gumanitarnye nauki [Journal of Siberian Federal University. - Humanities], 6, 870-881.

Libakova, N.M. \& Sertakova, E.A. (2014). Metodologiia prikladnykh etnologicheskikh issledovanii severnykh territorii Rossii: preimushchestva ekspertnogo interv'iu [Methodology of applied ethnological studies of the northern territories of Russia: the advantages of expert interviews]. In NB: Problemy obshchestva i politiki [NB: Problems of society and politics], 3, 67-86.

Luk'yanov, G.I. \& Ignatov, V.N. (2012). Otnoshenie k istoricheskomu proshlomu kak faktor formirovaniia sotsiokul'turnoi identichnosti [Attitude to the historical past as a factor in the formation of socio-cultural identity]. In Filosofiia i kultura [Philosophy and culture], 6, 88-95.

Luzan V.S. (2011). Osobennosti pravovogo regulirovaniia sotsiokul'turnogo razvitiia korennykh malochislennykh narodov Severa, Sibiri i Dal'nego Vostoka v usloviiakh global'nykh transformatsii [Features of legal regulation of socio-cultural development of indigenous peoples of the North, Siberia and the Far East in the context of global transformations]. In Zhurnal Sibirskogo federal'nogo universiteta [Journal of Siberian Federal University], 4 (5), 678-686.

Luzan V.S. (2015). Spetsifika realizatsii gosudarstvennoi kul'turnoi politiki v mestakh prozhivaniia korennkh malochislennykh narodov Severa, Sibiri i Dal'nego Vostoka (v Rossiiskoi Federatsii) [The specifics of the implementation of the state cultural policy in the places of residence of the indigenous minorities of the North, Siberia and the Far East (in the Russian Federation)]. In Sovremennyye problemy nauki i obrazovaniya [Modern problems of science and education], 1, $1885 \mathrm{p}$.

Luzan, V.S. (2014). Mekhanizmy vzaimodeistviia gosudarstva, biznesa s korennymi malochislennymi narodami Severa, Sibiri i Dal'nego Vostoka v usloviiakh 
global'nykh transformatsii [Mechanisms of interaction of the state, business with indigenous peoples of the North, Siberia and the Far East in the context of global transformations]. In NB: Problemy obshchestva i politiki [NB: Problems of society and politics], 3, 50-66.

Makarenko, A.A. (1962). Russkaya fol'kloristika Sibiri (XIX - nachala XX vv.) [Russian folklore of Siberia (19 th - beginning of 20 th centuries)]. Tomsk, 221-253.

Makarov, N.P. (2013). Drevnie etapy kul'turogeneza narodov Krasnoiarskogo Severa [The ancient stages of the culture Genesis of the peoples of Krasnoyarsk North]. In Zhurnal Sibirskogo federal'nogo universiteta [Journal of Siberian Federal University], 6 (6), 816-841.

Makusheva, M.O. (2017). Transformatsii identichnosti neneckoi molodezhi v inokul'turnoi srede [Transformation of identity of Nenets youth in a foreign cultural environment]. In Monitoring obshchestvennogo mneniia: Ekonomicheskie i sotsial'nye peremeny [Public opinion monitoring: Economic and social changes], 4, 54-65.

Mazepus, V.V. (1997). Muzykal'nye kul'tury Sibiri i prinysipy ikh opisaniia [Music cultures of Siberia and principles of their description]. In Muzykal'naia kul'tura Sibiri [Musical culture of Siberia], 1.

Mijatović, L.R. (2014). Imagining and Remembering City: Memory, Space and Symbolism of Belgrade. In Culture, (6), 97-106.

Mirkes, M.M. \& Sergeyeva, N.A. (2011). Kodifikatsiia kul'turnykh znachenii v ornamentakh ulits goroda Krasnoiarska [Codification of cultural values in the ornaments of the streets of the city of Krasnoyarsk]. In Journal of Siberian Federal University. Humanitarian sciences, 4 (12), 1794-1806.

Moskalyuk, M.V., Koptseva, N.P., Pimenova, N.N., Kistova, A.V., Sertakova, E.A., $\&$ Kharitonov, V.V. (2016). Study of air conditioning systems for storage and display of art works. In ARPN Journal of Engineering and Applied Sciences, 11(23), 13878-13883.

Nas, P.J.M. (2011). Cities Full of Symbols: A Theory of Urban Space and Culture. Leiden University Press, 305 p.

Pal'chin, S. Ia. (2013). Nyneshnie sotsial'nye i ekonomicheskie dannye o korennykh malochislennykh narodakh Severa s 2012 goda [Current social and economic data on indigenous minorities of the North since 2012]. In Zhurnal Sibirskogo federal'nogo universiteta [Journal of Siberian Federal University], 6 (6), 913-924.

Pavlova, T.V. (1997). Obryadovyy fol'klor evenov Yakutii (muzykal'noetnograficheskiy aspekt) [Ritual folklore of the Evens of Yakutia (musical and ethnographic aspect)]. Novosibirsk. 
Pimenova, N.N. (2015). Mekhanizmy sotsiokul'turnykh izmenenii korennykh etnosov Severa $i$ Sibiri [Mechanisms of sociocultural changes of indigenous ethnic groups of the North and Siberia]. Krasnoyarsk, 183 p.

Povoroznyuk, O.A. \& Funk, D.A. (2016). Urbanizatsiia i korennye narody Severa: vvedenie k teme nomera [Urbanization and indigenous peoples of the North: introduction to the theme of the issue]. In Etnograficheskoe obozrenie [Ethnographic review], 1, 5-9.

Rezanova, Z.I. (2012). Semioticheskaia reprezentatsiia natsional'no-kul'turnoi identichnosti $\mathrm{v}$ tekste goroda [Semiotic representation of national-cultural identity in the text of the city]. In Vestnik Tomskogo gosudarstvennogo universiteta. Kul'turologiia $i$ iskusstvovedenie [Tomsk State University Bulletin. Cultural studies and art history], (3), 19-26.

Reznikova, K., Seredkina, N., Koptseva, N., \& Zamaraeva, J. (2016). Regional specifics of social values and their impact on Central Siberian territories' modernization (based on research of Krasnoyarsk region). In Economic Annals-XXI, 160(7-8), 92-95.

Reznikova, K.V. (2016). Obraz migrantov v predstavleniiakh sovremennykh studentov (na materiale analiza Krasnoiarskogo kraia i Sibirskogo federal'nogo universiteta) [The image of migrants in the views of modern students (based on the analysis of the Krasnoyarsk Territory and the Siberian Federal University)]. In Sotsiodinamika [Sociodynamics], 2, 77-88.

Reznikova, K.V. (2013). Sokhranenie i transformatsiia nekotorykh aspektov traditsionnogo obraza zhizni korennykh i malochislennykh narodov Severa, prozhivayushchikh $\mathrm{v}$ naselennykh punktakh (poselkakh) Turukhansk i Farkovo [Preservation and Transformation of Certain Aspects of the Traditional Way of Life of the Indigenous and Small-Numbered Peoples of the North, Living in the Settlements (Posyolki) of Turukhansk and Farkovo]. In Zhurnal Sibirskogo federal'nogo universiteta. - Gumanitarnye nauki [Journal of Siberian Federal University. Humanities], 6, 925-939.

Reznikova, K.V., Seredkina, N.N., Zamaraeva, Y.S., \& Koptseva, N.P. (2017). The traditional economy of indigenous peoples of central Siberia (the case of the Selkups). In International Journal of Economic Research, 14(15), 261-270.

Romanova, E.N. (2008). Voennaia kul'tura i ee osnovnye kharakteristiki [Military culture and its main characteristics]. In Vestnic SAMSU [Messenger SAMSU], 1, 213.

Scherbakova, A.S. (2013). Etnoistoricheskoe razvitie russkogo naseleniia Bashkortostana: problemy interpretatsii [Ethnohistorical development of the Russian 
population of Bashkortostan: problems of interpretation]. In Sovremennye problemy nauki i obrazovaniia [Modern problems of science and education], 1, 414-420.

Semenova, A.A. \& Bralkova, A.V. (2011). Vizualizatsiia kontsepta 'sever' v izobrazitel'nom iskusstve [Visualization of the concept of 'north' in the visual arts]. In Zhurnal Sibirskogo federal'nogo universiteta [Journal of Siberian Federal University], 4.4, 476-491.

Senyavskaya, E.S. (2004). Voennaia antropologiia kak novaia nauchnaia distsiplina: perspektivy razvitiia i znachenie dlia oboronosposobnosti Rossii [Military anthropology as new scientific discipline: prospects of development and value for defense capability of Russia]. In Vestnik Akademii Voennikh nauk [Messenger of Academy of Military Sciences], 3 (8).

Seredkina, N.N. \& Smolina, M.G. (2018). Educational potential of epics and fairy tales of indigenous minority peoples of Siberia. In Novosibirsk State Pedagogical University Bulletin, (4), 217-232.

Sertakova, E.A. \& Avdonina, E. Yu. (2016). Vynuzhdennaia migratsiia i ee otrazhenie $\mathrm{v}$ kinematograficheskom iskusstve [Forced migration and its reflection in cinematographic art]. In Sotsiodinamika [Sociodynamics], 2, 106-116

Sertakova, E.A. \& Gerasimova, A.A. (2015). Obraz goroda Krasnoiarska v ksilografii i problema regional'noi identichnosti [The image of the city of Krasnoyarsk in woodcuts and the problem of regional identity]. In Urbanistika [Urban Studies], 2, 89-99.

Sertakova, E.A. \& Koptseva, N.P. (2015). Sotsiokul'turnoe prostranstvo sovremennogo rossiiskogo goroda (na materiale analiza g. Krasnoiarska) [Sociocultural space of modern Russian city (based on the analysis of the city of Krasnoyarsk)]. Krasnoyarsk, $128 \mathrm{p}$.

Sertakova, E.A., Koptseva, N.P., Kolesnik, M.A., Libakova, N.M., Luzan, V.S., \& Sergeeva, N.A. (2016). Brand-management of Siberian Cities (Krasnoyarsk as a case study). In International Review of Management and Marketing, 6(5S), 185-191.

Sevoyan, D.G. \& Sunkov, A.P. (2013). Aktual'nye problemy obespecheniia sub'ektami Rossiiskoi Federatsii konstitucionnogo prava narodov na sohranenie rodnogo iazyka [Actual problems of ensuring by subjects of the Russian Federation of the constitutional right of the people to preservation of the native language]. In Pravo i politika [The Right and policy], 11, 1438-1443.

Shadrin, V.I. (2016). Transformatsiia etnicheskoi identichnosti korennykh malochislennykh narodov Severa Iakutii v usloviiakh globalizatsii (na primere iukagirov 
Respubliki Sakha (Iakutiia) [Transformation of ethnic identity of small indigenous peoples of the North of Yakutia in the context of globalization (on the example of Yukaghirs of the Republic of Sakha (Yakutia)]. In Arktika XXI vek. Gumanitarnye nauki [Arctic of the $21^{\text {st }}$ century. Humanities], 4(10), 132-144.

Sheikin, Yu.I. (2002). Istoriya muzykal'noy kul'tury narodov Sibiri [History of the musical culture of the peoples of Siberia]. Moscow: Vost. lit., $716 \mathrm{p}$.

Sihlongonyane, M.F. (2015). The rhetorical devices for marketing and branding Johannesburg as a city: a critical review. In Environment and Planning A. 47 (10), 2134-2152.

Silantyeva, N.A. (2015). Aktual'nye problemy sovremennogo razvitiia korennykh malochislennykh narodov severa [Actual problems of modern development of the indigenous peoples of the north]. In Severnyi region: nauka, obrazovanie, kul'tura [Northern region: science, education, culture], 2, 145-148

Sitnikova, A.A. (2015). Demografiia i migratsiia v poselkakh korennykh malochislennykh narodov Krasnoiarskogo kraia (poselki Pasechnoe, Essei, Surinda, Farkovo, Nosok, Karaul) [Demography and migration in the villages of indigenous minorities of the Krasnoyarsk Krai (villages Pasechnoye, Essey, Surinda, Farkovo, Nosok, Karaul)]. In Sovremennye problemy nauki i obrazovaniia [Modern problems of science and education], 1-1,229

Sitnikova, A.A., Pimenova, N.N. \& Filko, A.I. (2018). Pedagogical approaches to teaching and adaptation of indigenous minority peoples of the North in higher educational institutions. In Novosibirsk State Pedagogical University Bulletin, 8 (4), 26-45.

Smolina, M.G., Koptseva, N.P. \& Sertakova, E.A. (2018). Literature review on the urban environment of Krasnoyarsk. In Journal of Siberian Federal University. Humanities, 11(10), 1653-1672.

Spirina, T.A. \& Goroshko, E.A. (2017). Transformatsii etnicheskoi identichnosti studencheskoi molodezhi [Transformation of ethnic identity of students]. In Molodoi uchenyi [Young Scientist], 19, 282-285.

Stas', I.N. (2012). Kontsept 'gorod' v postmodernistskoi istoriografii [The concept of the 'city' in postmodern historiography]. In Vestnik Cheliabinskogo gosudarstvennogo universiteta [Bulletin of the Chelyabinsk state University], 11 (265), History, 50, 154-159.

Tarasova, M.V. (2010). Kommunikativnye osnovy khudozhestvennoi kul'tury [Communicative foundations of artistic culture]. Krasnoyarsk, SibFU, 179 p. 
Tarasova, M.V. (2015). Teoriia i praktika dialoga zritelia i proizvedeniia iskusstva [Theory and practice of a dialogue of the viewer with the work of art]. Krasnoyarsk, SibFU, 236 p.

Utaberta, N., Jalali, A., Johar, S., Surat, M. \& Che-Ani, A.I. (2012). Building Facade Study in Lahijan City, Iran: The Impact of Facade's Visual Elements on Historical Image. In International Journal of Social, Behavioral, Educational, Economic, Business and Industrial Engineering, 6 (7), 1839-1844.

Vasilevich, G.M. (1969). Evenki. Istoriko-etnograficheskie ocherki (XVII-XX vv.) [The Evenks. Historical and ethnographic notes (18 ${ }^{\text {th }}-20^{\text {th }}$ centuries)]. Leningrad, $304 \mathrm{p}$.

Weina, Ch. (2009). Decode the City: A Methodological Study Responding to the New Trend of City "Re-image” Montreal as a Case. School of Urban Planning, McGill University, Montreal, 75 p.

Zamaraeva, Ju.S. (2014). Teoriia, istoriografiia i metodologiia issledovaniia fenomena migratsii v kontekste sovremennoi filosofii kul'tury [Theory, historiography and research methodology of the phenomenon of migration in the context of the modern philosophy of culture]. In Sovremennye problemy nauki i obrazovaniia [Modern problems of science and education], 4, 227.

Zamaraeva, Yu.S. (2018). Experience in the Preservation and Development of the Evenki Language in the Evenki Municipal District of the Krasnoyarsk Krai on the Basis of the Analysis of Evenki Archival Documents. In Journal of Siberian Federal University. Humanities \& Social Sciences, 11 (8), 1327-1369.

Zamaraeva, Yu.S., Sergeeva, N.A. \& Fil'ko, A.I. (2018). Measures on the Preservation of the Language of the Small-numbered Indigenous Peoples Based on the Results of Field Studies and Scientific Research in the Evenk Municipal District of the Krasnoyarsk Krai. In Journal of Siberian Federal University. Humanities \& Social Sciences, 4 (11), 679-694

Zhukovskii, V.I. \& Koptseva, N.P. (2004). Propozitsii teorii izobrazitel'nogo iskusstva [The Propositions of the Theory of Fine Art]. Krasnoyarsk, KGU, 266 p.

Zhukovskii, V.I. (2011). Teoriia izobrazitel'nogo iskusstva [The theory of Fine Art, Krasnoyarsk]. St. Petersburg, Aleteiia, 496 p. 


\section{Обзор актуальных региональных культурных исследований (Красноярский край): \\ проблемы и подходы}

К.А. Дегтяренко, С. В. Метляева, Д. С. Пчелкина, А.И. Филько, А.А. Шпак, М.Я. Хребтов, К.И. Шиманская Сибирский федеральнылй университет Россия, 660041, Красноярск, пр. Свободньй, 79

В настоящей статье представлены результаты анализа актуальных региональных культурных исследований. Целью данного анализа было определить, какие направления культурных исследований в современном мире наиболее перспективны с точки зрения изучения культуры регионов. Конкретным примером послужили не только статьи зарубежных авторов, но также и исследования культуры, проводившиеся непосредственно в Красноярском крае. На основании обзора можно сделать вывод, что актуальными для Красноярского края на данный момент являются исследования в таких направлениях: этнокультурные прочессы, этническая идентичность и ее конструирование, трансформачия этноидентичности, язык и культура коренных малочисленных народов Севера, миграционные прочессы, городские исследования, современное искусство, арт-медиачия, музыкальный фольклор, концептьл «война» и «мир».

Ключевые слова: культурные исследования, Арктика, Красноярский край, региональные исследования, этнокультурные проиессы, этническая идентичность, арт-медиация, современное искусство, музыкальный фольклор, концепт, городские исследования.

Научная специальность: 17.00.00-искусствоведение; 24.00.00-культурология. 